\title{
The correlation between single nucleotide polymorphisms of the thymic stromal lymphopoietin receptor and breast cancer in a cohort of female patients in Saudi Arabia
}

『Abdelhabib Semlali ( $\sim$ abdelhabib.semlali@greb.ulaval.ca )

Université Laval: Universite Laval https://orcid.org/0000-0002-1643-0377

Mikhlid H. Almutairi

King Saud University

Sultan N. Alharbi

King Abdulaziz City for Science And Technology

Abdullah M. Alamri

King Saud University

Abdulwahed F. Alrefaei

King Saud bin Abdulaziz University for Health Sciences

Bader O. Almutairi

King Saud University

Mahmoud Rouabhia

Universite Laval

\section{Research Article}

Keywords: TSLPR, Polymorphisms, Breast cancer progression, TSLPR expression

Posted Date: May 11th, 2021

DOl: https://doi.org/10.21203/rs.3.rs-456721/v1

License: (c) (1) This work is licensed under a Creative Commons Attribution 4.0 International License. Read Full License

Version of Record: A version of this preprint was published at Environmental Science and Pollution Research on July 13th, 2021. See the published version at https://doi.org/10.1007/s11356-021-15242-1. 


\section{Abstract}

The current study aimed to examine thymic stromal lymphopoietin receptor (TSLPR) genetic variation and breast cancer (BC) susceptibility in women in Saudi Arabia. Therefore, 127 blood samples from female patients diagnosed with $B C$ and 116 blood samples from healthy female controls were studied using a genotyping assay to determine the association between three TSLPR single nucleotide polymorphisms (SNPs)-P196L, X201W, and A238V-and the risk of BC progression. In addition, gene expression was evaluated in 20 matching $B C$ and normal tissues using immunohistochemistry. TSLPR protein levels were higher among $B C$ patients than those with matching normal breast tissue. In addition, $T S L P R$ SNP P196L was found to have a significant protective effect on $\mathrm{BC}$ progression $(\mathrm{OR}=0.4427)$, although only the T allele for TSLPRP196L had this protective effect against BC progression in participants who were younger than 48 years old. In contrast, no association was found between the $T$ allele and risk of BC in participants who were older than 48 years old, and the CT and TT genotypes were significantly associated with BC risk protection in the older group. The effects of the TT genotype and the $T$ allele were closely associated with a decreased risk of BC in participants with estrogen receptors (ER+) and without them (ER-). Overall, the findings revealed a significant correlation between SNPs in the TSLPR genes and BC progression among women in Saudi Arabia.

\section{Introduction}

Breast cancer $(\mathrm{BC})$ is a main cause of morbidity and mortality among females around the world, especially in industrialized countries, and is the main cause of death among women in Saudi Arabia. It is a heterogeneous inflammatory disease that is caused by a variety of genetic lesions, including in genes related to proliferation, such as cell cycle genes, tumor suppressor genes, and innate immunity genes. A total of $60 \%$ of premenopausal women and $75 \%$ of postmenopausal women have estrogen receptors $(E R+)$, which depend on estrogen for the proliferation of cancer cells and tumor growth (Hiscox et al., 2009, Santen et al., 2009).

Our previous studies on the genetic variations of Toll-like receptors have uncovered the nature of multiple genetic aberrations (Semlali et al., 2017a, Semlali et al., 2017b, Semlali et al., 2016). Other evidence has suggested that inflammatory molecules could play an important role in breast tumor development and progression thymic stromal lymphopoietin (TSLP), a category of inflammatory molecules involved in host immune responses, and its receptor, TSLPR, have been largely overlooked in the study of cancer (Corren and Ziegler, 2019).

TSLP is an inflammatory cytokine that promotes Th2-mediated inflammatory immune responses (Soumelis et al., 2002, Ziegler, 2010) and is released by malignant cells in humans (Xie et al., 2013). Previous study has proposed that malignancy-derived TSLP could act on TSLPR + endothelial cells to encourage angiogenesis in cervical tumors (Xie et al., 2013). Also, it has been shown that a Th2 response largely dominated the cytotoxicity induced by CD8 T cells and T-helper 1 (Th1) response in many types of cancers (Loose and Van de Wiele, 2009, Pedroza-Gonzalez et al., 2011). However, tumors with this type of 
phenotype are more aggressive than tumors in which Th1-like responses predominate (Aspord et al., 2007, De Monte et al., 2011).

A recent study reported that a high production of TSLP via malignant cells can decrease the antitumor activities of Th1 cells (Lo Kuan and Ziegler, 2014). Nevertheless, the role of TSLP in tumor susceptibility remains controversial (Yue et al., 2016). Yue et al. (2016) reported that TSLP function can inhibit colon tumor growth in humans by encouraging the apoptosis of malignant cells (Yue et al., 2016).

TSLPR is a heterodimeric cytokine receptor that forms two subunits: TSLPR (also known as cytokine receptor-like factor 2) (Jia et al., 2015) and the 7IL-7Ra chain (which is common for IL-7)(Pandey et al., 2000, Park et al., 2000, Reche et al., 2001, Zhong and Pandey, 2010), TSLP and TSLPR play essential roles in allergic disorders, including atopic dermatitis (AD) and allergic bronchial asthma (Sebastian et al., 2008, Ziegler, 2010). Recent work has shown that TSLP and TSLPR are also involved in the genesis of malignant cells, such as BC and pancreatic cancer (Olkhanud et al., 2011).

The TSLPR gene was first recognized in a human T lymphocyte cDNA library (Tonozuka et al., 2001, Zhang et al., 2001). It is located on the Xp22.3 and Yp11.3, and the mature protein has a molecular mass of $39,698 \mathrm{kDa}$. The TSLPR structure is comprised of four conserved cysteine residues, two fibronectin type III-like domains and a WSXWS (Trp-Ser-X-Trp-Ser) box-like motif. The TSLPR C-terminal intracellular region has a membrane-proximal box 1 motif, which serves as a binding site for signal transduction molecules (Tonozuka et al., 2001, Zhang et al., 2001).

By binding to its receptors, TSLP can activate the JAK-STAT signaling pathway to increase proliferation and eosinophils chemotaxis. TSLP and TSLPR can both trigger several signaling transduction pathways, including JAK/STAT, PI3K/Akt/mTOR, nuclear factor-KB (NF-KB), extracellular-signal-regulated kinase 1/2 (ERK1/2), P38 mitogen-activated protein kinases (P38MAPK), and c-Jun N-terminal kinase 1/2 (JNK1/2) (Redhu and Gounni, 2012, Ren et al., 2016). It has been documented that TSLP-induced high expression of the same surface markers, such as CD40 and CD54, promotes the secretion of many cytokines and chemokines via the TSLPR heterocomplex (Durum, 2014, Zheng et al., 2010).

The relationship between TSLPR genetic variations, such as polymorphisms, and inflammatory diseases, especially asthma, has been studied in many populations (Shamim et al., 2007, Sinha et al., 2015). They identified 20 single nucleotide polymorphisms (SNPs) in the TSLPR gene of humans, and TSLPR SNPs were found to be closely associated with atopic asthma development in a study of Korean individuals (Yu et al., 2010). Meanwhile, Sherill et al. documented an association between polymorphic variants of TSLP and TSLPR and eosinophilic esophagitis (Sherrill et al., 2010), eczema herpeticum, and AD (Gao et al., 2010). Furthermore, we recently found that malignant breast tumors displayed higher level of TSLP expression than benign breast tumors; we also found a significant correlation between SNPs within the TSLP gene and an increased risk of BC in the Saudi population (Semlali et al., 2019b). However, the role of TSLPR SNPs (P196L, X201W, and A238V) in BC remains unclear. 
We expected that many TSLPR genetic polymorphisms might be prognostic factors of BC recurrence. Therefore, we aimed to determine the expression and potential association between TSLPR SNPs and the risk of BC development among women in Saudi Arabia. It is a considerable challenge for many scientists to use dysregulated TSLP/TSLPR signaling in therapeutic applications (Verstraete et al., 2017).

\section{Materials And Methods}

\section{Ethics, controls, and BC group characteristics}

The bloods samples and breast tissues used in this study were donated by Abdulrahman Al Naeem (from King Fahad Medical City (KFMC), Riyadh, Saudi Arabia), and Sana Abdulla Ajaj (from the Department of Family Medicine, College of Medicine, King Saud University, Riyadh, Saudi Arabia). This study was approved by the KFMC institutional review board committee (local ethics committee number 15-089E), and written consent was obtained from all participants.

We obtained genomic DNA from $127 \mathrm{BC}$ patients and 116 healthy controls. The median age of the participants was $48 \pm 8.2$. In the BC group, $35.43 \%$ were younger than 48 years old, and $64.57 \%$ were older than 48 years old. In the control group, $53.45 \%$ were younger than 48 years old, and $46.55 \%$ were older than 48 years old. All participants were Saudi women. Data on age, family history of cancer, medical conditions, behavior, and estrogen receptor (ER) status was collected via questionnaire (Table 1). Qualified histopathologists confirmed all BC patients' diagnoses. None of the control group participants had a history of cancer. Formalin-fixed paraffin-embedded tumor tissues from $10 \mathrm{BC}$ patients were collected at KFMC.

\section{Immunohistochemistry assay}

To investigate the link between TSLPR protein levels and BC cancer progression, 10 tissue specimens were fixed in $10 \%$ formalin and then embedded in paraffin. The TSLPR protein level was quantified using the immunohistochemistry (IHC) technique as described in our previous works (Semlali et al., 2015, Semlali et al., 2010, Semlali et al., 2017a, Semlali et al., 2016). A specialized pathologist at King Khalid University Hospital (KKUH) performed the immunohistochemical interpretation with an ultraView DAB Detection Kit. Briefly, the paraffinized sections were cut into $3 \mu \mathrm{m}$-thick slices, placed on coated slides, deparaffinized, and rehydrated. The rehydrated slides were put in an incubator overnight at $37^{\circ} \mathrm{C}$ and then placed in a hot air oven for 30 minutes at $60^{\circ} \mathrm{C}$, processed in an automated IHC slide staining system, and incubated separately with either anti-TSLPR antibody $(1: 100)$ for an hour at $37^{\circ} \mathrm{C}$. The immunolocalized TSLPR proteins were photographed through a copper-enhanced DAB reaction. Finally, the immunostained sections were reviewed using a microscope.

\section{Genomic DNA extraction}

For genomic DNA isolation, DNA was extracted from $200 \mu \mathrm{l}$ of each whole blood sample based on the genomic DNA extraction kit manufacturer's instructions (Qiagen, Courtaboeuf, France). All samples were 
lysed, and then proteinase $\mathrm{K}$ was added. After incubation $\left(10 \mathrm{~min}\right.$ at $\left.56^{\circ} \mathrm{C}\right)$, the lysates were transferred into a DNA column placed in a $2 \mathrm{ml}$ collection tube until the other cell constituents passed through and then centrifuged for $15 \mathrm{~s}$ at $\geq 10,000 \mathrm{rpm}$. After two wash steps, any remaining contamination was removed, and pure high molecular weight of DNA was eluted using RNase free water. The purity and concentration of the extracted DNA were measured using a NanoDrop Lite Spectrophotometer. The isolated DNA specimens were kept at $-20^{\circ} \mathrm{C}$ for further investigation.

\section{Selection of SNPs and genotyping assays}

Genotyping analysis of the TSLPR SNPs-rs36139698 (P196L), rs36177645 (X201W), and rs36133495 (A238V) - was carried out using the TaqMan allelic discrimination assay, as described in our previous studies (Alanazi et al., 2013, Semlali et al., 2017a, Semlali et al., 2017b, Semlali et al., 2016). These SNPs are situated in the exon of the TSLPR gene, and they were selected via the public domain of the dbSNP (http://www.ncbi.nlm.nih.gov/snp). Three major criteria were considered when selecting the TSLPR SNPs: 1) a minor allele frequency of more than $0.05,2$ ) localization in the gene-coding region, and 3 ) associations with cancer risk, as described in the literature.

A genotyping assay was performed in a 96-well plate with a real-time PCR device from Applied Biosystem. PCR amplifications were performed in a $10 \mu \mathrm{L}$ reaction mixture comprised of DNA (10-20 ng), 2X TaqMan Universal Master Mix (5.6 $\mu \mathrm{L})$, and $200 \mathrm{nM}$ of each primer. All primers and probe mixtures used in this study were purchased Applied Biosystems. Reactions were carried out and analyzed using the QuantStudio 7 Flex qPCR System and software from Life Technologies.

\section{Structural modeling}

The secondary structure of the TSLPR protein sequence was generated using Geneious software v10.0.3 (Kearse et al., 2012). As a result, a three-dimensional (3D) structure of TSLPR protein containing 370 residues was predicted after submitting the protein sequence to the Phyre2 server (http://www.sbg.bio.ic.ac.uk/phyre2/html/page.cgi?id=index).

\section{Statistical methods}

The collected data was evaluated with Hardy-Weinberg equilibrium (http://ihg2.helmholtzmuenchen.de/cgi-bin/hw/hwa1.pl), and Chi-square analysis was conducted in SPSS v16.0 (SPSS, Chicago, USA) to determine the relationship between the BC and control groups and the TSLPR variants. The results were represented as odds ratios (ORs) with 95\% confidence interval (Cl). Fisher's exact test was applied to correct the difference in the genotype and allele frequency distribution between the $\mathrm{BC}$ and control groups. The outcomes were considered statistically significant when $P<0.05$.

\section{Results}


To assess the TSLPR protein levels in BC, we compared the TSLPR protein levels in BC adenomas with those in normal tissues from the same patients using the IHC assay (Figure 1). TSLPR immunostaining revealed that the $\mathrm{BC}$ epitheliums in the tissues surrounding the malignant tumor had a much higher degree of positive staining than the normal breast tissues (Figure 1).

\section{Single nucleotide polymorphism associations of the TSLPR gene in the BC and control groups}

We examined whether genetic variants of TSLPR were correlated with the BC group and/or the control group. Three TSLPR SNPs (P196L (C/T), X201W (A/G), and A238V (C/T)) were genotyped and assessed using HWE analyses. The genotype allocations of the TSLPR SNPs among the $\mathrm{BC}$ and control groups are presented in Table 2. Only P196L had a statistically significant relationship with a decreased risk of BC development in all tested genotypes and alleles. The results showed that $38 \%, 49 \%$, and $87 \%$ of the BC group carried the CT, TT, and CT+TT genotypes, respectively, while $34 \%, 60 \%$, and $94 \%$ of the control group carried the CT, TT, and CT+TT genotypes, respectively (CT: OR $=0.4427, P=0.0498 ; \mathrm{TT}$ :

$\mathrm{OR}=0.3273, P=0.0052 ;$ and $\mathrm{CT}+\mathrm{TT}: \mathrm{OR}=0.3693, P=0.0103)$.

In addition, the $\mathrm{T}$ allele showed a lower risk of $\mathrm{BC}$ development in $68 \%$ of the $\mathrm{BC}$ group compared to $77 \%$ of control group $(P=0.0067)$. Meanwhile, the frequencies of the X201W genotypes and alleles did not differ between the study groups. The genotypic allocations in the BC group were $5 \% A A, 40 \% A G$, and $55 \%$ GG for X201W and 17\% CC, 48\% CT, and 35\% TT for A238V. The genotypic allocations in the control group were $6 \% \mathrm{AA}, 46 \% \mathrm{AG}$, and $48 \% \mathrm{GG}$ for $\mathrm{X} 201 \mathrm{~W}$ and $23 \% \mathrm{CC}, 47 \% \mathrm{CT}$, and $30 \%$ TT for $\mathrm{A} 238 \mathrm{~V}$. Furthermore, the $\mathrm{G}$ and $\mathrm{T}$ alleles did not present any variations in terms of allele frequency compared to the wild $\mathrm{A}$ and $\mathrm{C}$ alleles in the $\mathrm{BC}$ and control groups for $\mathrm{X} 201 \mathrm{~W}$ and $\mathrm{A} 238 \mathrm{~V}$, respectively (Table 2).

\section{Differences in TSLPR polymorphisms according to BC patient's age at diagnosis}

Since the median age of $\mathrm{BC}$ diagnosis among the $\mathrm{BC}$ participants was 48 years old, we tested the relationship between the analyzed TSLPR SNPs and age at BC diagnosis by separating the participants into the following categories: younger than 48 years old (35.43\%) and older than 48 years old (64.57\%). $\mathrm{X} 201 \mathrm{~W}$ and $\mathrm{A} 238 \mathrm{~V}$ were associated with an increased risk of BC in the former group but not the latter group (Tables $3 \mathrm{~A}$ and $3 \mathrm{~B}$, respectively).

Furthermore, in the younger group, the genotype distribution for X201W was $46 \%$ for $A G, 52 \%$ for $G G$, and $98 \%$ for $A G+G G$ among the $B C$ patients and $39 \%$ for $A G, 52 \%$ for $G G$, and $91 \%$ for $A G+G G$ among the control patients (AG: OR $=5.77, P=0.0081 ; \mathrm{GG}: \mathrm{OR}=4.89, P=0.0184 ; \mathrm{AG}+\mathrm{GG}: \mathrm{OR}=5.27, P=0.0093$ ) (Table $3 \mathrm{~A}$ ). For $\mathrm{A} 238 \mathrm{~V}$, the risk of $\mathrm{BC}$ development was approximately 2.3 times for the $\mathrm{CT}$, TT, and CT+TT genotypes than for the $\mathrm{CC}$ homozygous allele (CT: $\mathrm{OR}=2.36, P=0.0406$; TT: $\mathrm{OR}=2.28, P=0.0682$; and $\mathrm{CT}+\mathrm{TT}: \mathrm{OR}=2.33, P=0.0304)$ (Table 3A). Meanwhile, no significant associations were found between the $\mathrm{G}$ allele of $\mathrm{X} 201 \mathrm{~W}$ and the T allele of $\mathrm{A} 238 \mathrm{~V}$ and the $\mathrm{A}$ and $\mathrm{C}$ alleles, respectively. However, the $\mathrm{T}$ allele of $\mathrm{P} 196 \mathrm{~L}$ was associated with a lower risk of $\mathrm{BC}$ compared to the $\mathrm{C}$ reference allele $(\mathrm{OR}=0.57, P=$ 0.0309). 
In contrast, in the older than 48 years old group, X201W and A238V did not present any genetic variations between the $\mathrm{BC}$ and control groups (Table 3B). Meanwhile, the genotype frequency for $\mathrm{P} 196 \mathrm{~L}$ offered significant $\mathrm{BC}$ risk protection. In addition, the $\mathrm{CT}, \mathrm{TT}$, and $\mathrm{CT}+\mathrm{TT}$ genotypes were correlated with a decreased risk of BC ( $P=0.0014,0.0018$, and 0.0009 , respectively) (Table 3B). The T, G, and T alleles of $\mathrm{P} 196 \mathrm{~L}, \mathrm{X} 201 \mathrm{~W}$, and $\mathrm{A} 238 \mathrm{~V}$, respectively, did not show any significant correlations compared to the $\mathrm{C}, \mathrm{A}$, and $\mathrm{C}$ reference alleles, respectively (Table $3 \mathrm{~B}$ ).

\section{TSLPR genotype and allele frequency variation based on ER status}

We also analyzed the associations between the three TSLPR SNPs and patients' clinicopathological features, including ER status. X201W and A238V were not associated with a risk of BC based on ER+ or ER- status (Tables 4A and 4B). The genotype distribution for X201W was $36 \%$ for $A G, 58 \%$ for $G G$, and $94 \%$ for $A G+G G$ in $B C$ patients with $E R+$ and $49 \%$ for $A G, 49 \%$ for $G G$, and $98 \%$ for $A G+G G$ in $B C$ patients with ER-. For the ER+ and ER- in the control group, the results were $46 \%$ for $A G, 48 \%$ for $G G$, and $94 \%$ for AG++GG. The genotype distribution for $\mathrm{A} 238 \mathrm{~V}$ was $48 \%$ for $\mathrm{CT}, 34 \%$ for TT, and $82 \%$ for $\mathrm{CT}+\mathrm{TT}$ in $\mathrm{BC}$ patients with $\mathrm{ER}+$ and $53 \%$ for $\mathrm{CT}, 30 \%$ for TT, and $80 \%$ for $\mathrm{CT}+\mathrm{TT}$ in $\mathrm{BC}$ patients with ER-. For the ER+ and ER- patients in the control group, the results were $47 \%$ for $\mathrm{CT}, 30 \%$ for TT, and $77 \%$ for CT+TT (Tables $4 A$ and $A B)$.

Conversely, for $\mathrm{P} 196 \mathrm{~L}$, there was a significant association between all genotypes and alleles tested and $\mathrm{BC}$ risk protection with $\mathrm{ER}+(\mathrm{CT}: \mathrm{OR}=0.35, P=0.0404 ; \mathrm{TT}: \mathrm{OR}=0.31, P=0.0200 ; \mathrm{CT}+\mathrm{TT}: \mathrm{OR}=0.33, P=$ $0.0221)$ and the T allele $(O R=0.63, P=0.0439)$ (Table 4A). However, in contrast with the CC genotype and the $\mathrm{C}$ allele, the TT genotype and the $\mathrm{T}$ allele were associated with $\mathrm{BC}$ risk protection in ER-patients ( $P=0.0417$ and $P=0.0076$, respectively) (Table 4B).

\section{Secondary and 3D structures of TSLPR protein}

The primary structure of the TSLPR protein was utilized to generate its secondary structure, which revealed the first level of protein folding. The generated structure suggested that the TSLPR protein is composed of 8 a-helices and $25 \beta$-strands (Figure 2 ) and that the $\beta$-strands form two highly conserved immunoglobulin-like $\beta$-sandwich folds with approximately 185 residues (from 31 to 216) (Figure 3). In addition, proline residue (P196) seems to be crucial for the stability or folding of immunoglobulin-like $\beta$ sandwich domains of TSLPR, and it is located at domain-domain boundaries (Figure 3 ). This suggests that TSLPR is stabilized by this inter-proline residue, making the two domains of TSLPR conformally suitable for its ligand TSLP.

\section{Discussion}

TSLP contains a four-helix bundle cytokine that plays a pivotal role in tumors and inflammatory respiratory diseases (Corren and Ziegler, 2019). However, the factors inducing the activation of TSLP in cancer are not clearly defined. In the past few years, TSLP has been explored as a potential contributor to tumor-immune cell crosstalk. In addition, investigations of TSLP in malignancies have been motivated 
by the presence of Th2-promoting factors in some malignancies, raising the hypothesis that Th2 may be generated by cancer cells (Varricchi et al., 2018, Protti and De Monte, 2012). According to this rationale, it was suggested that the TSLP gene plays a role in human BC as a key cytokine generated via cancer epithelial cells and stimulates T helper cells to generate IL-13, a prototypical Th2 cytokine (PedrozaGonzalez et al., 2011).

Since TSLP, only signals through its receptor when the TSLPR chain dimerizes with the IL-7 receptorspecific chain (IL-7Ra), we used IHC to evaluate TSLPR expression on different cellular compartments of $\mathrm{BC}$ tissues and matched normal tissues. We also aimed to identify the correlations between TSLPR polymorphisms and the risk of BC development. Our data indicated that TSLPR protein levels were significantly higher in $\mathrm{BC}$ tissues compared to normal breast tissues. This interesting finding shows that it is possible that TSLPR contributes to qualitative or quantitative alterations in the microenvironment during BC susceptibility. In addition, mutation or epigenetic changes in the TSLPR promoter increase its accessibility to various transcriptional factors and, therefore, greatly induce the expression of the TSLPR gene (Olkhanud et al., 2011, Semlali et al., 2019b).

TSLP and TSLPR are widely expressed in vivo in many types of cells and have been implicated in a number of pathological disorders (Varricchi et al., 2018, Ziegler, 2010). However, TSLP/TSLPR expression was found to be higher in inflammatory diseases. A prevous work showed that TSLP plays an essential role in tumor progression, the tumor microenvironment, and metastasis, particularly in BC (Olkhanud et al., 2011). Erdmann et al. (2013) showed that a lack of functional TSLPR can induce mitigation of Th2 polarization and significantly decrease the growth of 4T1 primary breast tumors (Erdmann et al., 2013). Those data indicated that TSLP stimulates the progression of primary BC tumors, which is concordant with the findings of other studies (Olkhanud et al., 2011, Pedroza-Gonzalez et al., 2011). PedrozaGonzalez et al. (2011) showed that BC cell-derived TSLP leads to an inflammatory Th2 microenvironment that is conducive to BC development by activating OX40L expression on DCs (Pedroza-Gonzalez et al., 2011). Meanwhile, in a study of murine cancer cells, Olkhanud et al. (2011) clearly indicated that TSLP plays a critical role in cancer escape; however, TSLP inactivation was sufficient for virtually all abrogate malignancy development (Olkhanud et al., 2011). This finding conflicts with the results of a recent study that identified the important role played by TSLP protein levels in breast milk (Macfarlane et al., 2010) in the intestinal immunity of neonates (Thornton and Morgan, 2009). Meanwhile, Ghirelli et al. (2016) found no evidence of TSLP pathway activity in BC among humans (Ghirelli et al., 2016). Hence, the mechanisms leading to the deregulation of TSLPR expression remain unclear.

In the current study, we supposed that epigenetic changes, such as polymorphism in the regulatory regions of the TSLPR gene acquired during BC development phases were closely associated with a risk of $B C$ in the Saudi female population. Overall, our findings suggested that TSLPR polymorphism, especially exon polymorphisms of $\mathrm{P} 196 \mathrm{~L}$ but not $\mathrm{X} 201 \mathrm{~W}$ and $\mathrm{A} 238 \mathrm{~V}$, is an important factor in BC susceptibility in Saudi women. Only the genotype distribution of the P196L was found to be associated with BC susceptibility. This variant of TSLPR can reduce STAT pathway capacity and, hence, decrease 
inflammation, indicating the profound ability of the TSLP pathway to induce or reduce BC cancer development and progression.

In addition, proline residue seems to be crucial for the stability or folding of immunoglobulin-like $\beta$ sandwich domains of TSLPR located at domain-domain boundaries (Figure 3). This suggests that TSLPR is stabilized by this inter-proline residue, making the two domains of TSLPR conformally suitable for its ligand TSLP. BC control group had a significantly higher minor homozygote (TT) frequency of $\mathrm{P} 196 \mathrm{~L}$ than $\mathrm{BC}$ cases with an OR of approximately 0.3 , which means that this polymorphism has a protective effect against risk of $B C$ progression. These results are consistent a study that found that TSLPR P196L was a protector risk factor for AD in European Americans (Gao et al., 2010). Meanwhile, Yu et al. (2010) reported that TSLPR might be a candidate gene that is involved with atopic asthma pathogenesis in the Korean population (Yu et al., 2010).

To investigate the potential association between age at diagnosis and ER status among Saudi women with BC, we performed age- and ER-stratified analyses for the TSLPR polymorphisms. Bioinformatics' analysis suggested that the $\mathrm{X} 201 \mathrm{~W}$ and $\mathrm{A} 238 \mathrm{~V}$ variants of $T S L P R$ increased the risk of $\mathrm{BC}$ development by more than five times in participants who were younger than 48 years old; however, no link was found to ER status. Meanwhile, the association between the protective role of P196L, especially among participants who were older than 48 years old, and ER+ status was linked to menopause since estrogen levels were significantly decreased. In addition, the X201W and A238V variants increased stability compared with the wild-type protein, which could conceivably prolong TSLP-induced signal transduction

and induce BC progression in women in Saudi Arabia (Cheng et al., 2006). Semlali (2019) showed that TSLP and TSLPR polymorphisms were correlated with smoking behavior (Semlali et al., 2019a). Another study of Saudi subjects showed that the genotype and the allele frequencies of TSLP variants were connected with an increased risk of BC (Semlali et al., 2019b).

\section{Conclusion}

The present study illustrates the significant relationship between TSLPR polymorphic variants and BC in women in Saudi Arabia. The polymorphisms of these genes may be important in BC development. However, further research is needed to understand this relationship since a limited number of BC samples were used in this study. In addition, independent studies of other ethnic groups are required to investigate the relevance of the observed correlations with $B C$ susceptibility. We believe that the association between the studied SNPs and the risk of BC could contribute to the development of alternative tools that may serve as biomarkers for the early detection of $\mathrm{BC}$.

\section{Declarations}

Author contributions 
Abdelhabib Semlali: project administration, supervision, writing- review and editing of the manuscript; Mikhlid Almutairi: writing original draft of the manuscript, conceptualization, and funding acquisition; Sultan Alharbi: formal analysis and software; Abdullah Alamri: methodology and investigation; Abdulwahed Alrefaei: Data curation and methodology; Bader Almutairi: investigation, and validation; Mahmoud Rouabhia: resources, and consultant of the project

Funding: The authors extend their appreciation to the Deanship of Scientific Research at King Saud University for funding this work through research group no. (RG-1440-044)

Data availability: All data generated or analyzed during this study are included in this published article.

\section{Declarations}

Ethics approval and consent to participate: The bloods samples and breast tissues were donated by Abdulrahman Al Naeem, and Sana Abdulla Ajaj. This study was approved by the King Fahad Medical City (Riyadh, Saudi Arabia) institutional review board committee (local ethics committee number 15-089E). Each participant signed consent of written informed document for participating in the current study. All methods were performed in accordance with the relevant guidelines and regulations.

Consent for publication: Not applicable.

Competing interests: The authors declare no competing interests.

\section{References}

ALANAZI, M., PATHAN, A. A., ABDULJALEEL, Z., SHAIK, J. P., ALABDULKARIM, H. A., SEMLALI, A., BAZZI, M. D. \& PARINE, N. R. 2013. Association between PARP-1 V762A polymorphism and breast cancer susceptibility in Saudi population. PLoS One, 8, e85541.

ASPORD, C., PEDROZA-GONZALEZ, A., GALLEGOS, M., TINDLE, S., BURTON, E. C., SU, D., MARCHES, F., BANCHEREAU, J. \& PALUCKA, A. K. 2007. Breast cancer instructs dendritic cells to prime interleukin 13secreting CD4+ T cells that facilitate tumor development. J Exp Med, 204, 1037-47.

CHENG, J., RANDALL, A. \& BALDI, P. 2006. Prediction of protein stability changes for single-site mutations using support vector machines. Proteins, 62, 1125-32.

CORREN, J. \& ZIEGLER, S. F. 2019. TSLP: from allergy to cancer. Nat Immunol, 20, 1603-1609.

DE MONTE, L., RENI, M., TASSI, E., CLAVENNA, D., PAPA, I., RECALDE, H., BRAGA, M., DI CARLO, V., DOGLIONI, C. \& PROTTI, M. P. 2011. Intratumor T helper type 2 cell infiltrate correlates with cancerassociated fibroblast thymic stromal lymphopoietin production and reduced survival in pancreatic cancer. J Exp Med, 208, 469-78.

DURUM, S. K. 2014. IL-7 and TSLP receptors: twisted sisters. Blood, 124, 4-5. 
ERDMANN, R. B., GARTNER, J. G., LEONARD, W. J. \& ELLISON, C. A. 2013. Lack of functional TSLP receptors mitigates Th2 polarization and the establishment and growth of 4T1 primary breast tumours but has different effects on tumour quantities in the lung and brain. Scand $\mathrm{J}$ Immunol, 78, 408-18.

GAO, P. S., RAFAELS, N. M., MU, D., HAND, T., MURRAY, T., BOGUNIEWICZ, M., HATA, T., SCHNEIDER, L., HANIFIN, J. M., GALLO, R. L., GAO, L., BEATY, T. H., BECK, L. A., LEUNG, D. Y. \& BARNES, K. C. 2010. Genetic variants in thymic stromal lymphopoietin are associated with atopic dermatitis and eczema herpeticum. J Allergy Clin Immunol, 125, 1403-1407 e4.

GHIRELLI, C., SADACCA, B., REYAL, F., ZOLLINGER, R., MICHEA, P., SIRVEN, P., PATTARINI, L., MARTINEZCINGOLANI, C., GUILLOT-DELOST, M., NICOLAS, A., SCHOLER-DAHIREL, A. \& SOUMELIS, V. 2016. No evidence for TSLP pathway activity in human breast cancer. Oncoimmunology, 5, e1178438.

HISCOX, S., DAVIES, E. L. \& BARRETT-LEE, P. 2009. Aromatase inhibitors in breast cancer. Maturitas, 63, 275-9.

JIA, M., WANG, Z. J., ZHAO, H. Z., SHEN, H. P., CHENG, Y. P., LUO, Z. B. \& TANG, Y. M. 2015. Prognostic significance of cytokine receptor-like factor 2 alterations in acute lymphoblastic leukemia: a metaanalysis. World J Pediatr, 11, 126-33.

KEARSE, M., MOIR, R., WILSON, A., STONES-HAVAS, S., CHEUNG, M., STURROCK, S., BUXTON, S., COOPER, A., MARKOWITZ, S., DURAN, C., THIERER, T., ASHTON, B., MEINTJES, P. \& DRUMMOND, A. 2012. Geneious Basic: an integrated and extendable desktop software platform for the organization and analysis of sequence data. Bioinformatics, 28, 1647-9.

LO KUAN, E. \& ZIEGLER, S. F. 2014. Thymic stromal lymphopoietin and cancer. J Immunol, 193, 4283-8.

LOOSE, D. \& VAN DE WIELE, C. 2009. The immune system and cancer. Cancer Biother Radiopharm, 24, 369-76.

MACFARLANE, T. V., SEAGER, A. L., MOLLER, M., MORGAN, G. \& THORNTON, C. A. 2010. Thymic stromal lymphopoietin is present in human breast milk. Pediatr Allergy Immunol, 21, e454-6.

OLKHANUD, P. B., ROCHMAN, Y., BODOGAI, M., MALCHINKHUU, E., WEJKSZA, K., XU, M., GRESS, R. E., HESDORFFER, C., LEONARD, W. J. \& BIRAGYN, A. 2011. Thymic stromal lymphopoietin is a key mediator of breast cancer progression. $J$ Immunol, 186, 5656-62.

PANDEY, A., OZAKI, K., BAUMANN, H., LEVIN, S. D., PUEL, A., FARR, A. G., ZIEGLER, S. F., LEONARD, W. J. \& LODISH, H. F. 2000. Cloning of a receptor subunit required for signaling by thymic stromal lymphopoietin. Nat Immunol, 1, 59-64.

PARK, L. S., MARTIN, U., GARKA, K., GLINIAK, B., DI SANTO, J. P., MULLER, W., LARGAESPADA, D. A., COPELAND, N. G., JENKINS, N. A., FARR, A. G., ZIEGLER, S. F., MORRISSEY, P. J., PAXTON, R. \& SIMS, J. E. 
2000. Cloning of the murine thymic stromal lymphopoietin (TSLP) receptor: Formation of a functional heteromeric complex requires interleukin 7 receptor. J Exp Med, 192, 659-70.

PEDROZA-GONZALEZ, A., XU, K., WU, T. C., ASPORD, C., TINDLE, S., MARCHES, F., GALLEGOS, M., BURTON, E. C., SAVINO, D., HORI, T., TANAKA, Y., ZURAWSKI, S., ZURAWSKI, G., BOVER, L., LIU, Y. J., BANCHEREAU, J. \& PALUCKA, A. K. 2011. Thymic stromal lymphopoietin fosters human breast tumor growth by promoting type 2 inflammation. J Exp Med, 208, 479-90.

PROTTI, M. P. \& DE MONTE, L. 2012. Cross-talk within the tumor microenvironment mediates Th2-type inflammation in pancreatic cancer. Oncoimmunology, 1, 89-91.

RECHE, P. A., SOUMELIS, V., GORMAN, D. M., CLIFFORD, T., LIU, M., TRAVIS, M., ZURAWSKI, S. M., JOHNSTON, J., LIU, Y. J., SPITS, H., DE WAAL MALEFYT, R., KASTELEIN, R. A. \& BAZAN, J. F. 2001. Human thymic stromal lymphopoietin preferentially stimulates myeloid cells. J Immunol, 167, 336-43.

REDHU, N. S. \& GOUNNI, A. S. 2012. Function and mechanisms of TSLP/TSLPR complex in asthma and COPD. Clin Exp Allergy, 42, 994-1005.

REN, X., WANG, L. \& WU, X. 2016. A potential link between TSLP/TSLPR/STAT5 and TLR2/MyD88/NFkappaB-p65 in human corneal epithelial cells for Aspergillus fumigatus tolerance. Mol Immunol, 71, 98-106.

SANTEN, R. J., BRODIE, H., SIMPSON, E. R., SIITERI, P. K. \& BRODIE, A. 2009. History of aromatase: saga of an important biological mediator and therapeutic target. Endocr Rev, 30, 343-75.

SEBASTIAN, K., BOROWSKI, A., KUEPPER, M. \& FRIEDRICH, K. 2008. Signal transduction around thymic stromal lymphopoietin (TSLP) in atopic asthma. Cell Commun Signal, 6, 5 .

SEMLALI, A., AL AMRI, A., AZZI, A., AL SHAHRANI, O., ARAFAH, M., KOHAILAN, M., ALJEBREEN, A. M., ALHARBI, O., ALMADI, M. A., AZZAM, N. A., PARINE, N. R., ROUABHIA, M. \& ALANAZI, M. S. 2015.

Expression and new exon mutations of the human Beta defensins and their association on colon cancer development. PLoS One, 10, e0126868.

SEMLALI, A., ALMUTAIRI, M., AZZI, A., REDDY PARINE, N., ALAMRI, A., ALSULAMI, S., MESHAL ALUMRI, T., SAUD ALANAZI, M. \& ROUABHIA, M. 2019a. TSLP and TSLP receptors variants are associated with smoking. Mol Genet Genomic Med, 7, e842.

SEMLALI, A., ALMUTAIRI, M., REDDY PARINE, N., AL AMRI, A., ALMEER, R., ALANAZI, M. S. \& ROUABHIA, M. 2019b. Expression and allele frequencies of Thymic stromal lymphopoietin are a key factor of breast cancer risk. Mol Genet Genomic Med, 7, e813.

SEMLALI, A., JACQUES, E., KOUSSIH, L., GOUNNI, A. S. \& CHAKIR, J. 2010. Thymic stromal lymphopoietininduced human asthmatic airway epithelial cell proliferation through an IL-13-dependent pathway. $J$ Allergy Clin Immunol, 125, 844-50. 
SEMLALI, A., JALOUlI, M., PARINE, N. R., AL AMRI, A., ARAFAH, M., AL NAEEM, A., ABDULLAH AJAJ, S., ROUABHIA, M. \& ALANAZI, M. S. 2017a. Toll-like receptor 4 as a predictor of clinical outcomes of estrogen receptor-negative breast cancer in Saudi women. Onco Targets Ther, 10, 1207-1216.

SEMLALI, A., PARINE, N. R., AL AMRI, A., AZZI, A., ARAFAH, M., KOHAILAN, M., SHAIK, J. P., ALMADI, M. A., ALJEBREEN, A. M., ALHARBI, O., ALI AZZAM, N., ROUABHIA, M. \& ALANAZI, M. S. 2017b. Association between TLR-9 polymorphisms and colon cancer susceptibility in Saudi Arabian female patients. Onco Targets Ther, 10, 1-11.

SEMLALI, A., REDDY PARINE, N., ARAFAH, M., MANSOUR, L., AZZI, A., AL SHAHRANI, O., AL AMRI, A., SHAIK, J. P., ALJEBREEN, A. M., ALHARBI, O., ALMADI, M. A., AZZAM, N. A., KOHAILAN, M., ROUABHIA, M. \& ALANAZI, M. S. 2016. Expression and Polymorphism of Toll-Like Receptor 4 and Effect on NF-kappaB Mediated Inflammation in Colon Cancer Patients. PLoS One, 11, e0146333.

SHAMIM, Z., MULLER, K., SVEJGAARD, A., POULSEN, L. K., BODTGER, U. \& RYDER, L. P. 2007. Association between genetic polymorphisms in the human interleukin-7 receptor alpha-chain and inhalation allergy. Int J Immunogenet, 34, 149-51.

SHERRILL, J. D., GAO, P. S., STUCKE, E. M., BLANCHARD, C., COLLINS, M. H., PUTNAM, P. E., FRANCIOSI, J. P., KUSHNER, J. P., ABONIA, J. P., ASSA'AD, A. H., KOVACIC, M. B., BIAGINI MYERS, J. M., BOCHNER, B. S., HE, H., HERSHEY, G. K., MARTIN, L. J. \& ROTHENBERG, M. E. 2010. Variants of thymic stromal lymphopoietin and its receptor associate with eosinophilic esophagitis. J Allergy Clin Immunol, 126, 1605 e3.

SINHA, S., SINGH, J. \& JINDAL, S. K. 2015. Association of interleukin 7 receptor (rs1494555 and rs6897932) gene polymorphisms with asthma in a north Indian population. Allergy Rhinol (Providence), 6, 168-76.

SOUMELIS, V., RECHE, P. A., KANZLER, H., YUAN, W., EDWARD, G., HOMEY, B., GILLIET, M., HO, S., ANTONENKO, S., LAUERMA, A., SMITH, K., GORMAN, D., ZURAWSKI, S., ABRAMS, J., MENON, S., MCCLANAHAN, T., DE WAAL-MALEFYT RD, R., BAZAN, F., KASTELEIN, R. A. \& LIU, Y. J. 2002. Human epithelial cells trigger dendritic cell mediated allergic inflammation by producing TSLP. Nat Immunol, 3, 673-80.

THORNTON, C. A. \& MORGAN, G. 2009. Innate and adaptive immune pathways to tolerance. Nestle Nutr Workshop Ser Pediatr Program, 64, 45-57; discussion 57-61, 251-7.

TONOZUKA, Y., FUJIO, K., SUGIYAMA, T., NOSAKA, T., HIRAI, M. \& KITAMURA, T. 2001. Molecular cloning of a human novel type I cytokine receptor related to delta1/TSLPR. Cytogenet Cell Genet, 93, 23-5.

VARRICCHI, G., PECORARO, A., MARONE, G., CRISCUOLO, G., SPADARO, G., GENOVESE, A. \& MARONE, G. 2018. Thymic Stromal Lymphopoietin Isoforms, Inflammatory Disorders, and Cancer. Front Immunol, 9 , 1595. 
VERSTRAETE, K., PEELMAN, F., BRAUN, H., LOPEZ, J., VAN ROMPAEY, D., DANSERCOER, A., VANDENBERGHE, I., PAUWELS, K., TAVERNIER, J., LAMBRECHT, B. N., HAMMAD, H., DE WINTER, H., BEYAERT, R., LIPPENS, G. \& SAVVIDES, S. N. 2017. Structure and antagonism of the receptor complex mediated by human TSLP in allergy and asthma. Nat Commun, 8, 14937.

XIE, F., MENG, Y. H., LIU, L. B., CHANG, K. K., LI, H., LI, M. Q. \& LI, D. J. 2013. Cervical carcinoma cells stimulate the angiogenesis through TSLP promoting growth and activation of vascular endothelial cells. Am J Reprod Immunol, 70, 69-79.

YU, J. I., KANG, I. H., CHUN, S. W., YUN, K. J., MOON, H. B. \& CHAE, S. C. 2010. Identifying the polymorphisms in the thymic stromal lymphopoietin receptor (TSLPR) and their association with asthma. BMB Rep, 43, 499-505.

YUE, W., LIN, Y., YANG, X., LI, B., LIU, J. \& HE, R. 2016. Thymic stromal lymphopoietin (TSLP) inhibits human colon tumor growth by promoting apoptosis of tumor cells. Oncotarget, 7, 16840-54.

ZHANG, W., WANG, J., WANG, Q., CHEN, G., ZHANG, J., CHEN, T., WAN, T., ZHANG, Y. \& CAO, X. 2001. Identification of a novel type I cytokine receptor CRL2 preferentially expressed by human dendritic cells and activated monocytes. Biochem Biophys Res Commun, 281, 878-83.

ZHENG, X., MA, P., DE PAIVA, C. S., CUNNINGHAM, M. A., HWANG, C. S., PFLUGFELDER, S. C. \& LI, D. Q. 2010. TSLP and downstream molecules in experimental mouse allergic conjunctivitis. Invest Ophthalmol Vis Sci, 51, 3076-82.

ZHONG, J. \& PANDEY, A. 2010. Site-directed mutagenesis reveals a unique requirement for tyrosine residues in IL-7Ralpha and TSLPR cytoplasmic domains in TSLP-dependent cell proliferation. BMC Immunol, 11, 5.

ZIEGLER, S. F. 2010. The role of thymic stromal lymphopoietin (TSLP) in allergic disorders. Curr Opin Immunol, 22, 795-9.

\section{Tables}

Table 1. Clinical data of the BC and control groups 


\begin{tabular}{|c|c|c|}
\hline Character & $\begin{array}{l}\text { BC patients (\%) } \\
127(100 \%)\end{array}$ & $\begin{array}{l}\text { healthy controls (\%) } \\
116(100 \%)\end{array}$ \\
\hline $\begin{array}{l}\text { Age }(48 \pm 8.2) \\
\leq 48 \\
>48\end{array}$ & $\begin{array}{l}45(35.43 \%) \\
82(64.57 \%)\end{array}$ & $\begin{array}{l}62(53.45 \%) \\
54(46.55 \%)\end{array}$ \\
\hline $\begin{array}{l}\text { ER Status } \\
\text { Estrogen Receptor+ (ER+) } \\
\text { Estrogen Receptor- (ER-) } \\
\text { Undetermined }\end{array}$ & $\begin{array}{l}76(59.84 \%) \\
49(38.58 \%) \\
2(1.58 \%)\end{array}$ & $\begin{array}{l}- \\
-\end{array}$ \\
\hline $\begin{array}{l}\text { PR Status } \\
\text { Progesterone Receptor+ }+(\mathrm{PR}+) \\
\text { Progesterone Receptor- (PR-) } \\
\text { Undetermined }\end{array}$ & $\begin{array}{l}71(55.91 \%) \\
55(43.31 \%) \\
1(0.79 \%)\end{array}$ & $\begin{array}{l}- \\
- \\
-\end{array}$ \\
\hline $\begin{array}{l}\text { HER Status } \\
\text { HER+ } \\
\text { HER- }\end{array}$ & $\begin{array}{l}49(38.58 \%) \\
78(61.42 \%)\end{array}$ & - \\
\hline
\end{tabular}

Abbreviations: BC: breast cancer, ER: estrogen receptor, PR: progesterone receptor and HER: human epidermal growth factor receptor

Table 2. Genotype and allele allocations of TSLPR SNPs in the BC and control groups 


\begin{tabular}{|c|c|c|c|c|c|c|c|}
\hline $\begin{array}{c}\text { Amino } \\
\text { Acid } \\
\text { change }\end{array}$ & $\begin{array}{c}\text { Genotype } \\
\text { /allele }\end{array}$ & BC & Control & OR & $95 \% \mathrm{CI}$ & $\mathrm{X}^{2}$ & P value \\
\hline \multirow[t]{7}{*}{ (P196L) } & total & 135 & 186 & & & & \\
\hline & $\mathrm{CC}$ & $18(0.13)$ & $10(0.05)$ & Ref & & & \\
\hline & CT & $51(0.38)$ & $64(0.35)$ & 0.442708 & $\begin{array}{l}0.188- \\
1.0421\end{array}$ & 3.584837 & $0.04988^{*}$ \\
\hline & TT & $66(0.49)$ & $112(0.60)$ & 0.327381 & $\begin{array}{c}0.143- \\
0.7513\end{array}$ & 7.415995 & $0.005272 *$ \\
\hline & $\mathrm{CT}+\mathrm{TT}$ & $117(0.87)$ & $176(0.95)$ & 0.369318 & $\begin{array}{c}0.165- \\
0.8282\end{array}$ & 6.220476 & $0.010326^{*}$ \\
\hline & $\mathrm{C}$ & $87(0.32)$ & $84(0.23)$ & Ref & & & \\
\hline & $\mathrm{T}$ & $183(0.68)$ & $288(0.77)$ & 0.613506 & $\begin{array}{c}0.431- \\
0.8727 \\
\end{array}$ & 7.442535 & $0.0067 *$ \\
\hline \multirow[t]{7}{*}{$(\mathrm{X} 201 \mathrm{~W})$} & total & 131 & 187 & & & & \\
\hline & $\overline{\mathrm{AA}}$ & $6(0.05)$ & $11(0.06)$ & Ref & & & \\
\hline & AG & $52(0.40)$ & $86(0.46)$ & 1.1085 & $\begin{array}{r}0.387- \\
3.1762\end{array}$ & 0.036828 & 0.84615 \\
\hline & $\overline{G G}$ & $73(0.55)$ & $90(0.48)$ & 1.4870 & $\begin{array}{l}0.525- \\
4.2136\end{array}$ & 0.563117 & 0.43749 \\
\hline & $\mathrm{AG}+\mathrm{GG}$ & $125(0.95)$ & $176(0.94)$ & 1.3020 & $\begin{array}{l}0.4695- \\
3.6139 \\
\end{array}$ & 0.258155 & 0.60135 \\
\hline & $\mathrm{A}$ & $64(0.24)$ & $108(0.29)$ & Ref & & & \\
\hline & G & $198(0.76)$ & $266(0.71)$ & 1.2561 & $\begin{array}{c}0.877- \\
1.8 \\
\end{array}$ & 1.546005 & 0.2083 \\
\hline \multirow[t]{7}{*}{ (A238V) } & total & 150 & 185 & & & & \\
\hline & $\mathrm{CC}$ & $25(0.17)$ & $43(0.23)$ & Ref & & & \\
\hline & CT & $72(0.48)$ & $87(0.47)$ & 1.423 & $\begin{array}{c}0.794- \\
2.551 \\
\end{array}$ & 1.412 & 0.227 \\
\hline & $\mathrm{TT}$ & $53(0.35)$ & $55(0.30)$ & 1.657 & $\begin{array}{c}0.891- \\
3.083\end{array}$ & 2.562 & 0.104 \\
\hline & $\mathrm{CT}+\mathrm{TT}$ & $125(0.83)$ & $142(0.77)$ & 1.514 & $\begin{array}{l}0.875- \\
2.620 \\
\end{array}$ & 2.215 & 0.127 \\
\hline & $\mathrm{C}$ & $122(0.41)$ & $173(0.47)$ & Ref & & & \\
\hline & $\mathrm{T}$ & $178(0.59)$ & $197(0.53)$ & 1.281 & $\begin{array}{c}0.942- \\
1.743 \\
\end{array}$ & 2.493 & 0.113 \\
\hline
\end{tabular}

Note: Values in bold represent a significant result as ${ }^{*} P<0.05$.

Abbreviations: BC: breast cancer, Ref: reference allele, SNP: single nucleotide polymorphism, OR: odds ratio, P: Proline, L: Leucine, X: any amino acid, W: Tryptophan, A: Alanine, and V: Valine

Table 3. Genotype and allele allocations of TSLPR SNPs in the BC and control groups according to age 


\begin{tabular}{|c|c|c|c|c|c|c|c|}
\hline \multicolumn{8}{|c|}{ A) aged below 48 years } \\
\hline SNP & Genotype & $\overline{B C}$ & Control & OR & $95 \% \mathrm{CI}$ & $\mathrm{X}^{2}$ & $P$ value \\
\hline \multirow[t]{7}{*}{ (P196L) } & total & 63 & 92 & & & & \\
\hline & $\mathrm{CC}$ & $7(0.11)$ & $7(0.08)$ & Ref & & & \\
\hline & CT & $27(0.43)$ & $26(0.28)$ & 1.03846 & $\begin{array}{l}0.31974- \\
337272\end{array}$ & 0.003943 & 0.949932 \\
\hline & TT & $29(0.46)$ & $59(0.64)$ & 0.49153 & $\begin{array}{c}0.1575- \\
1.53391\end{array}$ & 1.536674 & 0.231915 \\
\hline & $\mathrm{CT}+\mathrm{TT}$ & $56(0.89)$ & $85(0.92)$ & 0.65882 & $\begin{array}{l}0.21916- \\
1.98047\end{array}$ & 0.558275 & 0.462067 \\
\hline & $\mathrm{C}$ & $41(0.33)$ & $40(0.22)$ & Ref & & & \\
\hline & $\mathrm{T}$ & $85(0.67)$ & $144(0.78)$ & 0.57588 & $\begin{array}{c}0.3453- \\
0.96043\end{array}$ & 4.519823 & $0.0309 *$ \\
\hline \multirow[t]{7}{*}{$(\mathrm{X} 201 \mathrm{~W})$} & total & 57 & 93 & & & & \\
\hline & $\overline{\mathrm{AA}}$ & $1(0.02)$ & $8(0.09)$ & $\overline{\operatorname{Ref}}$ & & & \\
\hline & $\overline{A G}$ & $26(0.46)$ & $36(0.39)$ & 5.77778 & $\begin{array}{c}0.68031- \\
49.0696\end{array}$ & 3.168579 & $0.008192^{*}$ \\
\hline & $\overline{\mathrm{GG}}$ & $30(0.52)$ & $49(0.52)$ & 4.89796 & $\begin{array}{l}0.58324- \\
41.1321\end{array}$ & 2.555308 & $0.01845^{*}$ \\
\hline & $\mathrm{AG}+\mathrm{GG}$ & $56(0.98)$ & $85(0.91)$ & 5.27059 & $\begin{array}{c}0.6415- \\
43.3032\end{array}$ & 2.938225 & $0.009312 *$ \\
\hline & $\overline{\mathrm{A}}$ & $28(0.25)$ & $52(0.28)$ & Ref & & & \\
\hline & $\mathrm{G}$ & $86(0.75)$ & $134(0.72)$ & 1.1919 & $\begin{array}{l}0.69924- \\
2.03166\end{array}$ & 0.416731 & 0.2389 \\
\hline \multirow[t]{7}{*}{$(\mathrm{A} 238 \mathrm{~V})$} & total & 71 & 91 & & & & \\
\hline & $\mathrm{CC}$ & $9(0.13)$ & $23(0.25)$ & Ref & & & \\
\hline & $\mathrm{CT}$ & $37(0.52)$ & $40(0.44)$ & 2.36389 & $\begin{array}{l}0.96985- \\
5.76167\end{array}$ & 3.680022 & $0.040603^{*}$ \\
\hline & TT & $25(0.35)$ & $28(0.31)$ & 2.28175 & $\begin{array}{l}0.89078- \\
5.84475\end{array}$ & 3.015428 & $0.06821 *$ \\
\hline & $\mathrm{CT}+\mathrm{TT}$ & $62(0.87)$ & $68(0.75)$ & 2.33007 & $\begin{array}{c}1.0019- \\
5.41889\end{array}$ & 3.993657 & $0.030489 *$ \\
\hline & $\mathrm{C}$ & $55(0.39)$ & $86(0.47)$ & Ref & & & \\
\hline & $\mathrm{T}$ & $87(0.61)$ & $96(0.53)$ & 1.41705 & $\begin{array}{c}0.9074- \\
2.21294\end{array}$ & 2.355861 & 0.1222 \\
\hline \multicolumn{8}{|c|}{ B) aged above 48 years } \\
\hline SNP & Genotype & BC & Control & OR & $95 \% \mathrm{CI}$ & $\mathrm{X}^{2}$ & P value \\
\hline \multirow[t]{7}{*}{ (P196L) } & total & 72 & 94 & & & & \\
\hline & $\mathrm{CC}$ & $11(0.15)$ & $3(0.03)$ & Ref & & & \\
\hline & CT & $24(0.33)$ & $38(0.41)$ & 0.172249 & $\begin{array}{c}0.04355- \\
0.68133\end{array}$ & 7.304562 & $0.001403^{*}$ \\
\hline & TT & $37(0.52)$ & $53(0.56)$ & 0.190395 & $\begin{array}{c}0.04966- \\
0.72997\end{array}$ & 6.840967 & $0.001859 *$ \\
\hline & $\mathrm{CT}+\mathrm{TT}$ & $61(0.85)$ & $91(0.97)$ & 0.182817 & $\begin{array}{l}0.04897- \\
0.68243\end{array}$ & 7.712279 & $0.000928 *$ \\
\hline & $\mathrm{C}$ & $46(0.32)$ & $44(0.23)$ & Ref & & & \\
\hline & $\mathrm{T}$ & $98(0.68)$ & $144(0.77)$ & 0.650966 & $\begin{array}{c}0.40019- \\
1.05889\end{array}$ & 3.009785 & 0.0839 \\
\hline \multirow{3}{*}{$(\mathrm{X} 201 \mathrm{~W})$} & total & 74 & 94 & & & & \\
\hline & AA & $5(0.07)$ & $3(0.03)$ & Ref & & & \\
\hline & $\overline{\mathrm{AG}}$ & $26(0.35)$ & $50(0.53)$ & 0.312 & $0.06908-$ & 2.487683 & 0.115211 \\
\hline
\end{tabular}




\begin{tabular}{|c|c|c|c|c|c|c|c|}
\hline & & & & & 1.40923 & & \\
\hline & $\overline{\mathrm{GG}}$ & $43(0.58)$ & $41(0.44)$ & 0.629268 & $\begin{array}{l}0.14126- \\
2.80318 \\
\end{array}$ & 0.374414 & 0.528917 \\
\hline & $\mathrm{AG}+\mathrm{GG}$ & $69(0.93)$ & $91(0.97)$ & 0.454945 & $\begin{array}{l}0.10511- \\
1.96914\end{array}$ & 1.160495 & 0.269806 \\
\hline & $\mathrm{A}$ & $36(0.24)$ & $56(0.30)$ & Ref & & & \\
\hline & $\bar{G}$ & $112(0.76)$ & $132(0.70)$ & 1.319865 & $\begin{array}{l}0.80973- \\
2.15139\end{array}$ & 1.24288 & 0.2595 \\
\hline \multirow[t]{7}{*}{ (A238V) } & total & 79 & 94 & & & & \\
\hline & $\mathrm{CC}$ & $16(0.20)$ & $20(0.21)$ & Ref & & & \\
\hline & CT & $35(0.44)$ & $47(0.50)$ & 0.930851 & $\begin{array}{l}0.42258- \\
2.05048 \\
\end{array}$ & 0.031632 & 0.859069 \\
\hline & TT & $28(0.36)$ & $27(0.29)$ & 1.296296 & $\begin{array}{l}0.55761- \\
3.01353 \\
\end{array}$ & 0.364121 & 0.544907 \\
\hline & $\mathrm{CT}+\mathrm{TT}$ & $63(0.80)$ & $74(0.79)$ & 1.064189 & $\begin{array}{l}0.50861- \\
2.22666\end{array}$ & 0.027283 & 0.868568 \\
\hline & $\mathrm{C}$ & $67(0.42)$ & $87(0.46)$ & Ref & & & \\
\hline & $\mathrm{T}$ & $91(0.58)$ & $101(0.54)$ & 1.169942 & $\begin{array}{c}0.76387- \\
1.79189\end{array}$ & 0.520997 & 0.4697 \\
\hline
\end{tabular}

Note: Values in bold represent a significant result as ${ }^{*} P<0.05$.

Abbreviations: BC: breast cancer, Ref: reference allele, SNP: single nucleotide polymorphism, OR: odds ratio. P:Proline, L: Leucine, X: any amino acid, W: Tryptophan, A: Alanine, and V: Valine

Table 4. Genotype and allele allocations of TSLPR SNPs in the BC and control groups according to estrogen status 


\begin{tabular}{|c|c|c|c|c|c|c|c|}
\hline \multicolumn{8}{|c|}{ A) Estrogen positive } \\
\hline SNP & Genotype & BC & Control & OR & $95 \% \mathrm{CI}$ & $\mathbf{X}^{2}$ & $P$ value \\
\hline \multirow[t]{7}{*}{ (P196L) } & total & 75 & 186 & & & & \\
\hline & $\mathrm{CC}$ & $11(0.15)$ & $10(0.05)$ & Ref & & & \\
\hline & CT & $25(0.33)$ & $64(0.35)$ & 0.35511 & $\begin{array}{c}0.13419- \\
0.93976\end{array}$ & 4.553663 & $0.040435^{*}$ \\
\hline & TT & $39(0.52)$ & $112(0.60)$ & 0.31656 & $\begin{array}{c}0.12481- \\
0.80288\end{array}$ & 6.30415 & $0.020097^{*}$ \\
\hline & $\mathrm{CT}+\mathrm{TT}$ & $64(0.85)$ & $176(0.95)$ & 0.33058 & $\begin{array}{l}0.13401- \\
0.81546\end{array}$ & 6.235134 & $0.022169 *$ \\
\hline & $\mathrm{C}$ & $47(0.31)$ & $84(0.23)$ & Ref & & & \\
\hline & $\mathrm{T}$ & $103(0.69)$ & $288(0.77)$ & 0.63918 & $\begin{array}{c}0.41912- \\
0.97479\end{array}$ & 4.356518 & $0.0439 *$ \\
\hline \multirow[t]{7}{*}{$(\mathrm{X} 201 \mathrm{~W})$} & total & 80 & 187 & & & & \\
\hline & $\overline{\mathrm{AA}}$ & $5(0.06)$ & $11(0.06)$ & Ref & & & \\
\hline & AG & $29(0.36)$ & $86(0.46)$ & 0.74186 & $\begin{array}{l}0.23777- \\
2.31464\end{array}$ & 0.26598 & 0.622788 \\
\hline & $\overline{\mathrm{GG}}$ & $46(0.58)$ & $90(0.48)$ & 1.12444 & $\begin{array}{l}0.36864- \\
3.42988\end{array}$ & 0.042527 & 0.833956 \\
\hline & $\mathrm{AG}+\mathrm{GG}$ & $75(0.94)$ & $176(0.94)$ & 0.9375 & $\begin{array}{l}0.31484- \\
2.79159\end{array}$ & 0.013443 & 0.908701 \\
\hline & $\bar{A}$ & $39(0.29)$ & $108(0.29)$ & Ref & & & \\
\hline & G & $121(0.71)$ & $266(0.71)$ & 1.25969 & $\begin{array}{l}0.8239- \\
1.92599\end{array}$ & 1.138457 & 0.2745 \\
\hline \multirow[t]{7}{*}{ (A238V) } & total & 85 & 185 & & & & \\
\hline & $\mathrm{CC}$ & $15(0.18)$ & $43(0.23)$ & Ref & & & \\
\hline & CT & $41(0.48)$ & $87(0.47)$ & 1.35096 & $\begin{array}{c}0.6741- \\
2.70746\end{array}$ & 0.721896 & 0.382454 \\
\hline & TT & $29(0.34)$ & $55(0.30)$ & 1.51152 & $\begin{array}{l}0.72109- \\
3.16839\end{array}$ & 1.203725 & 0.261784 \\
\hline & $\mathrm{CT}+\mathrm{TT}$ & $70(0.82)$ & $142(0.77)$ & 1.41315 & $\begin{array}{l}0.73497- \\
2.71709\end{array}$ & 1.081371 & 0.276992 \\
\hline & $\mathrm{C}$ & $71(0.42)$ & $173(0.47)$ & Ref & & & \\
\hline & $\mathrm{T}$ & $99(0.58)$ & $197(0.53)$ & 1.22449 & $\begin{array}{l}0.84842- \\
1.76726\end{array}$ & 1.171982 & 0.2764 \\
\hline \multicolumn{8}{|c|}{ B) Estrogen negative } \\
\hline SNP & Genotype & BC & Control & OR & $95 \% \mathrm{CI}$ & $\mathrm{X}^{2}$ & $P$ value \\
\hline \multirow[t]{7}{*}{ (P196L) } & total & 54 & 186 & & & & \\
\hline & $\mathrm{CC}$ & $7(0.13)$ & $10(0.05)$ & Ref & & & \\
\hline & CT & $25(0.46)$ & $64(0.35)$ & 0.55804 & $\begin{array}{c}0.19125- \\
1.62822\end{array}$ & 1.159887 & 0.307486 \\
\hline & TT & $22(0.41)$ & $112(0.60)$ & 0.28061 & $\begin{array}{c}0.09639- \\
0.81694 \\
\end{array}$ & 5.959689 & $0.041714^{*}$ \\
\hline & $\mathrm{CT}+\mathrm{TT}$ & $47(0.87)$ & $176(0.95)$ & 0.38149 & $\begin{array}{c}0.13783- \\
1.05595\end{array}$ & 3.659828 & 0.099104 \\
\hline & $\mathrm{C}$ & $39(0.36)$ & $84(0.23)$ & Ref & & & \\
\hline & $\mathrm{T}$ & $69(0.64)$ & $288(0.77)$ & 0.51603 & $\begin{array}{c}0.32518- \\
0.81889 \\
\end{array}$ & 8.040075 & $0.0076 *$ \\
\hline \multirow[t]{3}{*}{$(\mathrm{X} 201 \mathrm{~W})$} & total & 45 & 187 & & & & \\
\hline & $\mathrm{AA}$ & $1(0.02)$ & $11(0.06)$ & Ref & & & \\
\hline & AG & $22(0.49)$ & $86(0.46)$ & 2.81395 & $0.34458-$ & 1.01001 & 0.163657 \\
\hline
\end{tabular}




\begin{tabular}{|c|c|c|c|c|c|c|c|}
\hline & & & & & 22.9799 & & \\
\hline & GG & $22(0.49)$ & $90(0.48)$ & 2.68889 & $\begin{array}{l}0.32942- \\
21.9482\end{array}$ & 0.917615 & 0.189154 \\
\hline & $\mathrm{AG}+\mathrm{GG}$ & $44(0.98)$ & $176(0.94)$ & 2.75 & $\begin{array}{l}0.34575- \\
21.8727\end{array}$ & 0.990675 & 0.160153 \\
\hline & A & $24(0.27)$ & $108(0.29)$ & Ref & & & \\
\hline & $\bar{G}$ & $66(0.73)$ & $266(0.71)$ & 1.11654 & $\begin{array}{l}0.66516- \\
1.87423\end{array}$ & 0.174116 & 0.6718 \\
\hline \multirow[t]{7}{*}{ (A238V) } & total & 59 & 185 & & & & \\
\hline & $\mathrm{CC}$ & $10(0.17)$ & $43(0.23)$ & Ref & & & \\
\hline & CT & $31(0.53)$ & $87(0.47)$ & 1.53218 & $\begin{array}{c}0.68778- \\
3.4133\end{array}$ & 1.099697 & 0.268508 \\
\hline & $\mathrm{TT}$ & $18(0.30)$ & $55(0.30)$ & 1.40727 & $\begin{array}{l}0.58962- \\
3.35878\end{array}$ & 0.595503 & 0.430084 \\
\hline & $\mathrm{CT}+\mathrm{TT}$ & $49(0.83)$ & $142(0.77)$ & 1.4838 & $\begin{array}{c}0.69331- \\
3.1756\end{array}$ & 1.042246 & 0.27438 \\
\hline & $\mathrm{C}$ & $51(0.43)$ & $173(0.47)$ & Ref & & & \\
\hline & $\mathrm{T}$ & $67(0.57)$ & $197(0.53)$ & 1.15368 & $\begin{array}{c}0.75986- \\
1.7516\end{array}$ & 0.450587 & 0.5003 \\
\hline
\end{tabular}

Note: Values in bold represent a significant result as ${ }^{*} P<0.05$.

Abbreviations: BC: breast cancer, Ref: reference allele, SNP: single nucleotide polymorphism. OR: odds ratio. P: Proline, L: Leucine, X: any amino acid, W: Tryptophan, A: Alanine, and V: Valine

\section{Figures}



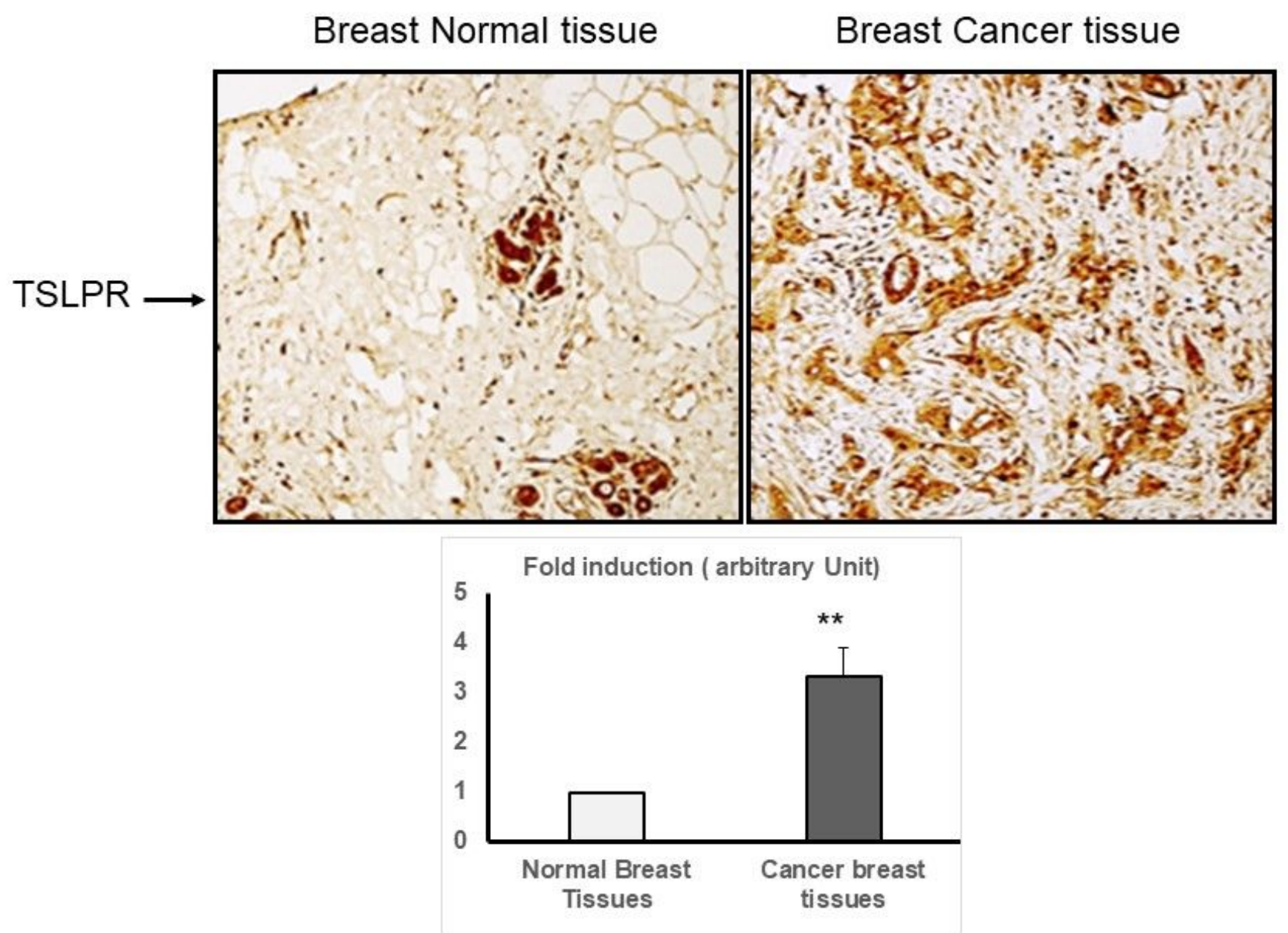

\section{Figure 1}

Expression of TSLPR protein levels: To investigate the link between TSLPR protein levels and BC progression, 10 tissue specimens were fixed in 10\% formalin and embedded in paraffin. The TSLPR protein level was quantified using the immunohistochemistry technique with an anti-TSLPR antibody (1:100). A) TSLPR expression in normal breast tissues. B) TSLPR expression in BC tissues. TSLPRpositive staining was estimated as follows: no positive color ( 0 points), $<20 \%$ positive staining ( 1 point), $21 \%-50 \%$ positive staining ( 2 points), $51 \%-75 \%$ positive staining ( 3 points), $>75 \%$ positive staining ( 4 points). 


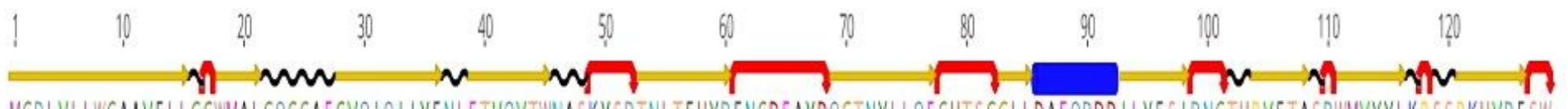

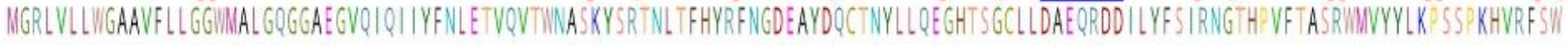
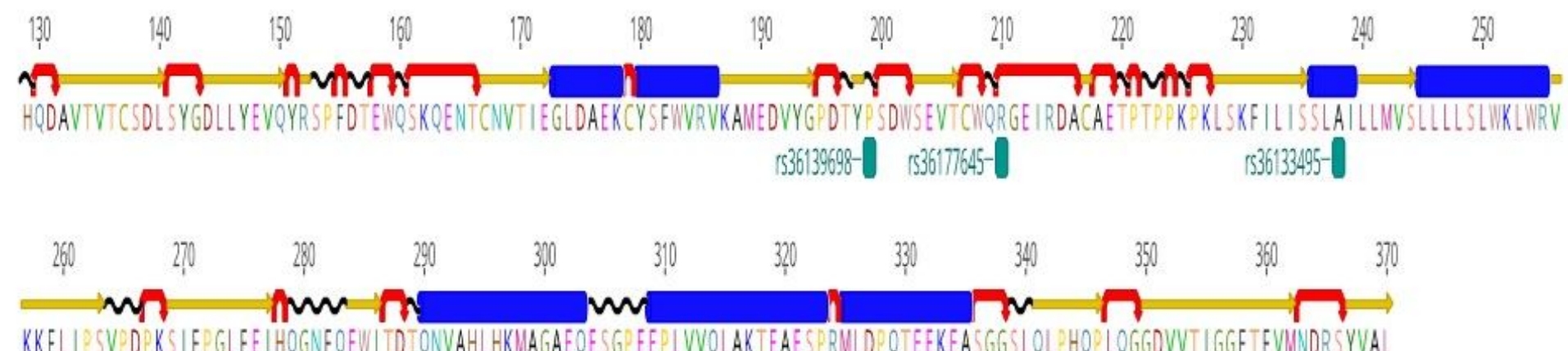

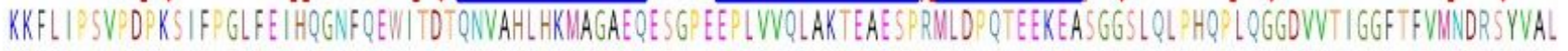

\section{Figure 2}

The secondary structure of the TSLPR protein (Accession number: XP_011543936.1): Yellow arrows and blue cylinders represent the beta-sheet and the alpha-helix, respectively. 


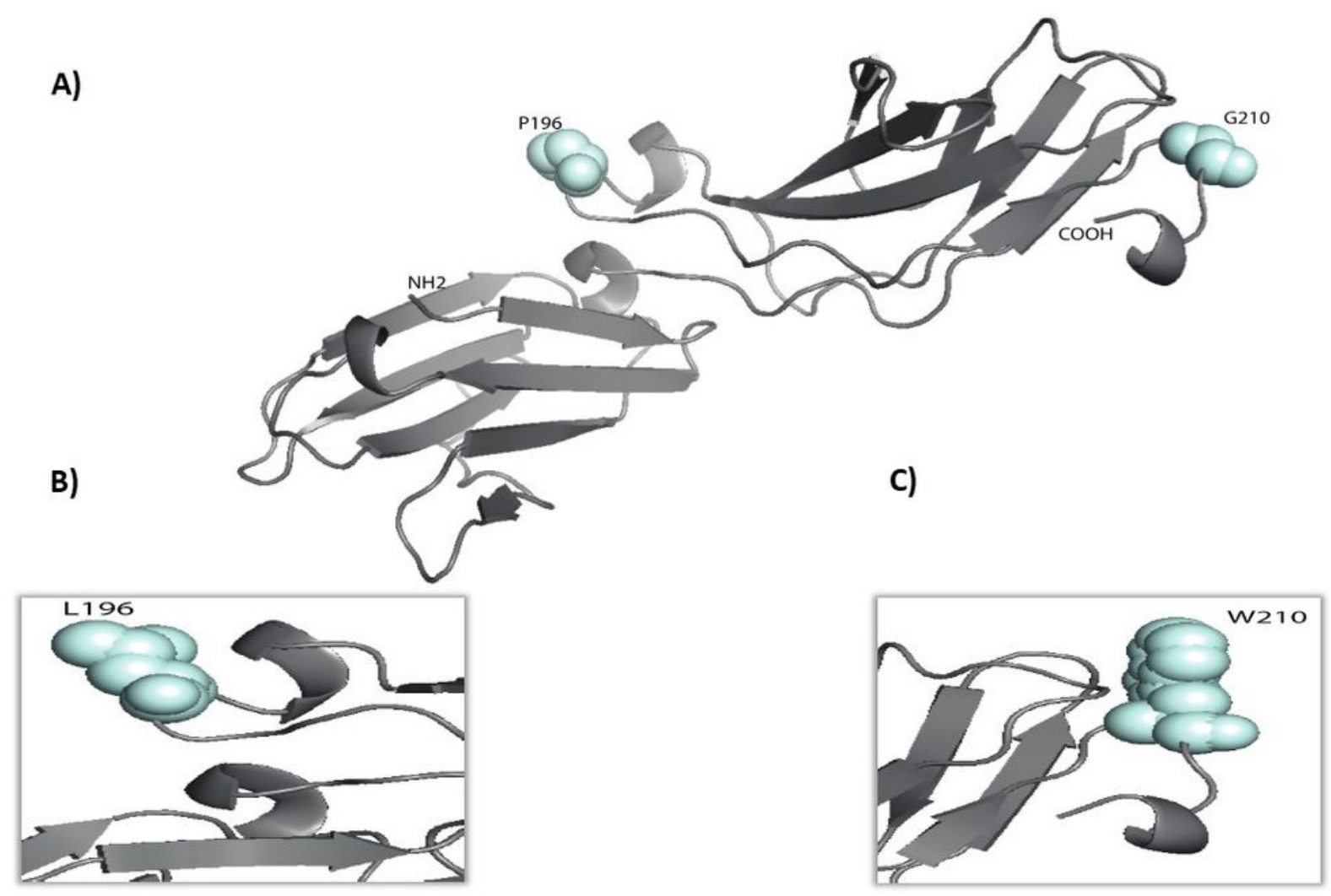

Figure 3

3D structure of TSLPR protein: A) Homology model (PDB ID: 5j12.1) of human TSLR, revealing the positions of P196 and G210 in representation spheres. B) Mutant L196 representation. C) Mutant W210 representation. 